\title{
Mapping and Expression of a Human Cytomegalovirus Major Viral Protein
}

\author{
MICHELLE GALL DAVIS, ${ }^{1 *}$ ENG-CHUNG MAR,${ }^{1}$ YUAN-MING WU,${ }^{1}+$ AND ENG-SHANG HUANG ${ }^{1,2.3}$ \\ Department of Medicine, ${ }^{2}$ Department of Microbiology and Immunology, ${ }^{3}$ and Cancer Research Center, ${ }^{1}$ University of \\ North Carolina, Chapel Hill, North Carolina 27514
}

Received 12 March 1984/Accepted 23 June 1984

\begin{abstract}
We constructed a DNA fragment map of low-passage Towne strain cytomegalovirus by analyzing cross-blot hybridization and hybridizations of isolated recombinant clones. The abundant late transcripts were located on this map by hybridization of labeled total RNA of virus-infected cells to blotted DNA fragments. The most abundant late transcript, carried by the 11.7-kilobase EcoRI fragment (EcoRI-G), was precisely mapped. The EcoRI fragment was fragmented and subcloned in a plasmid carrying simian virus 40 sequences (pSV-OH, constructed by Chi-Bom Chae, Department of Biochemistry, University of North Carolina, Chapel Hill). One resulting recombinant plasmid, pHD713SV2, was transferred to simian virus 40-transformed monkey kidney cells (COS-1) by DNA transfection. Synthesis of a cytomegalovirus-specific 67-kilodalton protein was detected in these cells by reaction of blotted proteins with virus-specific monoclonal antibody. The 67-kilodalton protein is a major phosphorylated protein found in virions; it is not glycosylated. The location of the gene for this 67 kilodalton protein is therefore assigned to the center of the L-unique region of human cytomegalovirus, at 0.37 to 0.39 map units.
\end{abstract}

Human cytomegalovirus (HCMV) is a herpesvirus associated with clinical manifestations ranging from asymptomatic infection to congenital abnormality, mental retardation, intrauterine death, or, in organ transplant patients, interstitial pneumonia. This virus can infect at multiple sites, and its antigenic diversity allows superinfection of seropositive individuals (9). Recently, it has been suggested that this virus has oncogenic potential comparable with those of other herpesviruses. Cytomegalovirus (CMV) was capable of stimulating cellular macromolecular synthesis (19) and transforming mammalian cells in vitro (14).

Physical maps of the double-stranded DNA genome of some laboratory strains have been constructed $(3,18 ; R$. L. LaFemina and G. S. Hayward, personal communication). In addition, recombinant DNA clones of these strains are available; this development will allow workers to define functional genes and compare specific portions of the genome from different strains to study gene function and expression. We have isolated recombinant DNA clones of CMV restriction fragments derived from Towne strain, passage 36, and constructed the DNA fragment map shown in Fig. 1. The restriction enzyme sites are not identical to those mapped by LaFemina and Hayward (Lafemina and Hayward, personal communication) for a high-passage Towne strain.

In this communication, we describe our study of abundant late transcripts. One of the most abundant late transcripts has been mapped to a small restriction fragment, and we have determined that this gene codes for one of the most abundant proteins in infected cells at the late stage of infection.

\section{MATERIALS AND METHODS}

Virus and viral DNA. HCMV Towne strain, passage 36, was used for all experiments. Virus was grown in WI-38

\footnotetext{
* Corresponding author.

$\dagger$ Permanent address: Wuhan Institute of Virology, Academy Sinica, Wuhan, China.
}

human fibroblasts, and virus DNA was isolated as previously described (8).

Enzymatic fragmentation of virus DNA and gel electrophoresis. Restriction enzymes were purchased from Bethesda Research Laboratories (BRL), and digestions were performed as recommended by the supplier. Agarose gels were run as previously described (17).

Transfer of DNA restriction fragments in gels to nitrocellulose. DNA was transferred to nitrocellulose paper by the procedure by Southern (17). Gels were soaked on $0.5 \mathrm{~N} \mathrm{HCl}$ solution for $15 \mathrm{~min}$ and then were transferred to a solution containing $0.5 \mathrm{M} \mathrm{NaOH}$ and $1 \mathrm{M} \mathrm{NaCl}$ for $15 \mathrm{~min}$ to denature the DNA. Finally, gels were neutralized by soaking for two 15 -min periods in a buffer solution containing $1 \mathrm{M}$ Tris hydrochloride $(\mathrm{pH} \mathrm{7.4)}$ and $1.5 \mathrm{M} \mathrm{NaCl}$. The DNA was transferred by blotting a transfer solution of $6 \times$ SSC $(1 \times$ SSC is $0.15 \mathrm{M} \mathrm{NaCl}$ plus $0.015 \mathrm{M}$ sodium citrate) through the gels, nitrocellulose paper, and absorbent paper.

Nick-translation of DNA. DNA was labeled for hybridization probe by incorporation of $\left[\alpha{ }^{32} \mathrm{P}\right]$ deoxyadenosine monophosphate. Each nick-translation mixture contained $0.5 \mu \mathrm{g}$ of DNA, $25 \mu \mathrm{Ci}$ of $\left[\alpha^{32} \mathrm{P}\right]$-dATP (ICN Biomedicals, Inc.), 0.1 $\mathrm{mM}$ dCTP, $0.1 \mathrm{mM}$ dGTP, $0.1 \mathrm{mM}$ TTP, $100 \mathrm{mM}$ Tris hydrochloride ( $\mathrm{pH} 7.5$ ), $20 \mathrm{mM} \mathrm{NaCl}, 5 \mathrm{mM} \beta$-mercaptoethanol, $5 \mathrm{mM} \mathrm{MgCl}_{2}, 2 \mathrm{U}$ of Poll (BRL) and $0.01 \mu \mathrm{g}$ of DNase (Worthington Biochemicals Corp.) per ml. After $1 \mathrm{~h}$ at $12^{\circ} \mathrm{C}$, reaction mixtures were applied to Sephadex G-100 columns eluted with $10 \mathrm{mM}$ Tris hydrochloride buffer $(\mathrm{pH} \mathrm{8)}$ containing $1 \mathrm{mM}$ EDTA, and the excluded peak was pooled.

Nucleic acid hybridizations. Hybridizations were done either in $6 \times$ SSC-0.1\% sodium dodecyl sulfate (SDS)-1 $1 \times$ Denhardt solution at $65^{\circ} \mathrm{C}$ for $20 \mathrm{~h}$ or in the same solution containing $10 \%$ dextran sulfate and $35 \%$ formamide at $45^{\circ} \mathrm{C}$ for $20 \mathrm{~h}$. Probe DNA was denatured by boiling along with competing nucleotides, including (per milliliter) $10 \mu \mathrm{g}$ of polyadenylic acid, $50 \mu \mathrm{g}$ of calf thymus DNA, $50 \mu \mathrm{g}$ of salmon testis DNA, and $50 \mu \mathrm{g}$ of yeast RNA; in hybridizations in which bacterial DNA was adhered to filters, $10 \mu \mathrm{g}$ of $E$. coli DNA per ml was added as a competitor. Concentra- 
tions of competing nucleotides are expressed as final amounts in the hybridization solutions. All filters were washed after hybridization, first at room temperature for 5 min in $2 \times \mathrm{SSC}$, and then three times at $55^{\circ} \mathrm{C}$ for $20 \mathrm{~min}$ in $0.1 \times$ SSC with $0.1 \%$ SDS. X-ray exposures of hybridized filters were sometimes enhanced by a Cronex Lightning-Plus intensifying screen and exposure at $-70^{\circ} \mathrm{C}$.

Cloning of DNA fragments of HCMV. A collection of recombinant plasmids carrying HCMV DNA was generated by enzymatic recombinations of EcoRI-digested DNA of HCMV Towne strain, passage 36, and EcoRI-digested pBR322 plasmid DNA. Ligation mixtures $(20 \mu \mathrm{l})$ contained
$0.5 \mu \mathrm{g}$ of pBR322 plasmid DNA, $1 \mu \mathrm{g}$ of fragmented HCMV DNA, $50 \mathrm{mM}$ Tris hydrochloride (pH 7.5), $10 \mathrm{mM} \mathrm{NaCl}, 10$ $\mathrm{mM}$ dithiothreitol, $50 \mu \mathrm{g}$ of bovine serum albumin per $\mathrm{ml}, 0.1$ $\mathrm{mM}$ ATP, $25 \mathrm{mM} \mathrm{MgCl}$, and $1 \mathrm{U}$ of T4 ligase (BRL). After incubation at $11^{\circ} \mathrm{C}$ overnight, the mixture was used to transform $E$. coli LE392 to ampicillin resistance. Bacterial colonies were tested for hybridization to HCMV DNA by the procedure described by Grunstein and Hogness (6). Some fragments eluted from gels by a procedure described by Maxam and Gilbert (12) were recombined similarly.

Subclones of $E c o R I$ recombinant plasmids were generated by redigestion of the $\mathrm{pBR} 322$ recombinant plasmids and

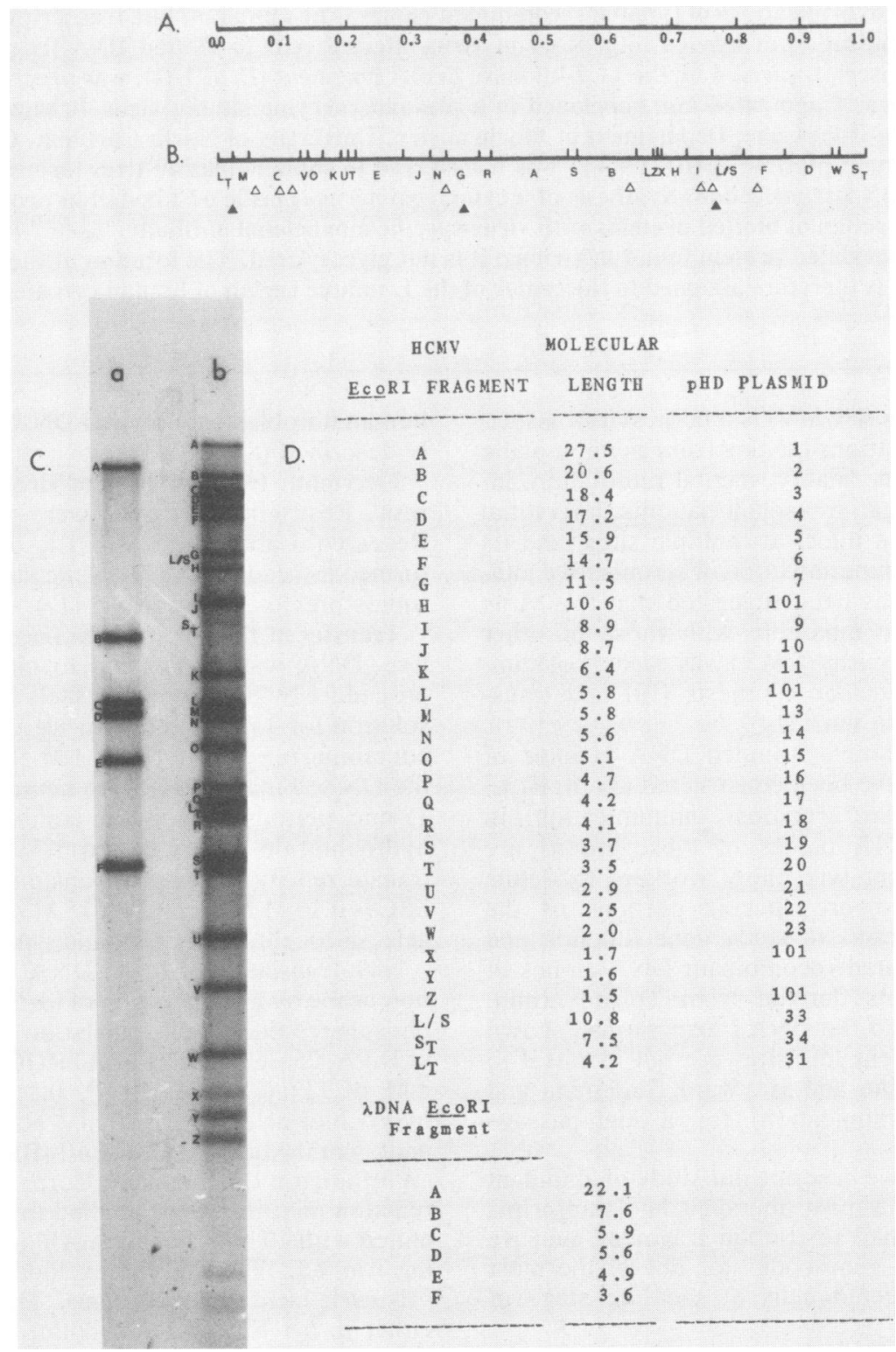

FIG. 1. Map of the recognition sites for EcoRI endonuclease on the DNA of CMV Towne strain, passage 36. (A) Fractional length of the DNA molecule. (B) Recognition sites for EcoRI endonuclease. $\triangle$, Sites which differ between this map and the sites determined by LaFemina and Hayward (Lafemina and Hayward, personal communication), and $\Delta$, DNA fragments which encode abundant late transcripts. (C) X-ray exposure of end-labeled fragments of $\lambda$ DNA (a) and HCMV DNA (b) digested with $E c o$ RI endonuclease. (D) Molecular length in kilobases of each EcoRI fragment and the designation of the recombinant plasmid carrying the fragment. Plasmid pHD101 is a pBR322 recombinant carrying HindIII-A of HCMV. Fragments which do not appear on this map are derived from the L-S junction (fragments P and Q) or appear to hybridize with fragments $\mathrm{X}$ and $\mathrm{Z}$ on cross-blot hybridization (fragment $\mathrm{Y}$ and fragments smaller than $1.5 \mathrm{~kb}$ ) but do not occur in plasmid pHD101. 
(A.)

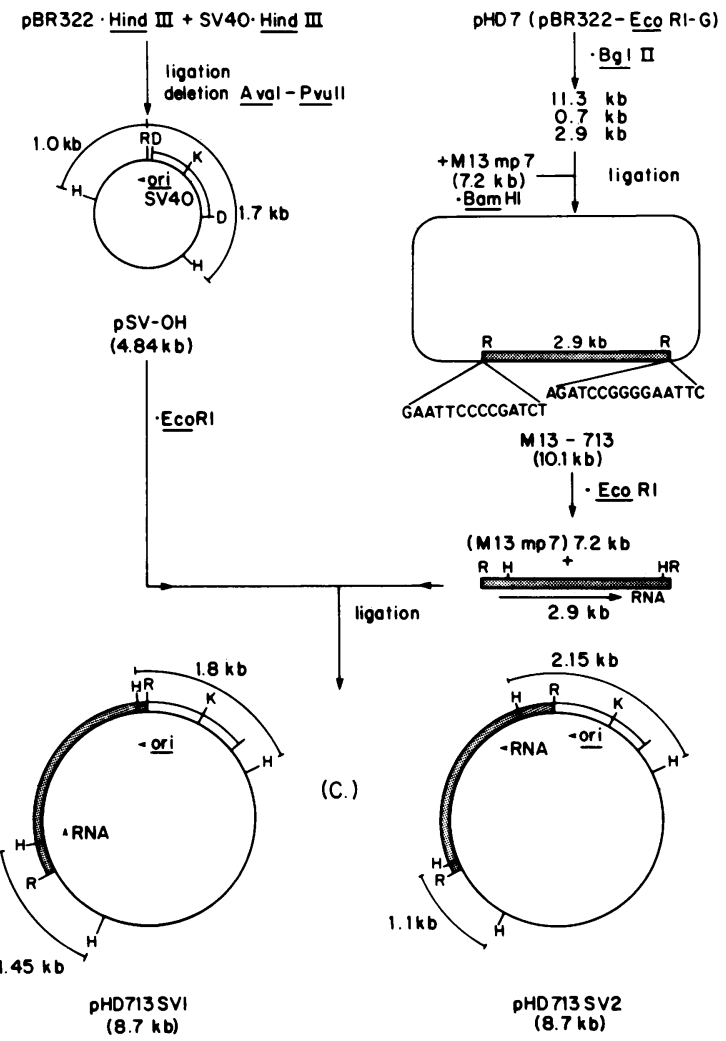

FIG. 2. Derivation of plasmids pHD713SV1 and pHD713SV2. (A) Plasmid pSV-OH was generated by recombination of pBR322 ) and SV40( $\square$ ) DNAs. The direction of ori is the same as the early promoter of SV40. (B) Fragments resulting from Bglll digestion of plasmid pHD7 were recombined with M13mp7 replicative form DNA digested with BamHI. The EcoRI sites are $10 \mathrm{bp}$ from the BamHI sites of the bacteriophage DNA. HCMV DNA. (C) The 2.9-kb fragment resulting from EcoRI digestion of M13-713 DNA was recombined with EcoRI-digested pSV-OH DNA. Recombinant plasmids were digested with Hinfl to determine the orientation of the inserted CMV DNA (data not shown). Enzyme sites indicated are: R, EcoRI; D, HindIII; K, KpnI; and H, HinfI.

enzymatic recombination with other vector DNAs (see the legend to Fig. 2 for detailed description of subclones).

The plasmid pSV-OH was isolated by C.-B. Chae of the Department of Biochemistry at the University of North Carolina at Chapel Hill (unpublished data). The plasmid was generated by enzymatic recombination of HindIII-digested simian virus 40 (SV40) DNA and HindIII-digested pBR322 DNA. A deletion between the $A v a$ I site at 1,424 base pairs (bp) and the $P v u I I$ site at 2,065 bp on pBR322 was also introduced to generate a 4.8-kilobase $(\mathrm{kb})$ vector, including SV40 sequences between the HindIII site at $5,107 \mathrm{bp}$ of SV40 and the origin of SV40 DNA replication and between the KpnI site at 230 bp and the HindIII site at 982 bp (C.-B. Chae, personal communication). A diagram of the plasmid is included in Fig. 2, indicating the direction of the SV40 sequences and the HinfI sites of pBR322 which were used to orient the CMV sequences in the recombinants pHD713SV1 and pHD713SV2.

Other recombinants were generated by enzymatic recombination of HindIII, BamHI, or BglII-digested HCMV DNA and plasmid pBR322 DNA or replicative form DNA of bacteriophage M13mp7.
RNA isolation. Cells were lysed with $7 \mathrm{M}$ guanidine hydrochloride and Sarkosyl and then layered over $6 \mathrm{M} \mathrm{CsCl}$ solution and centrifuged to separate RNA and DNA, as described by Seeburg et al. (16). RNA was extracted from the pellets.

RNA gel electrophoresis. RNA was separated on $0.8 \%$ agarose gels containing $6 \%$ formaldehyde and $20 \mathrm{mM}$ morpholinepropanesulfonic acid-acetic acid buffer at $\mathrm{pH} 7$ and 1 mM EDTA. After electrophoresis, RNA was blotted onto

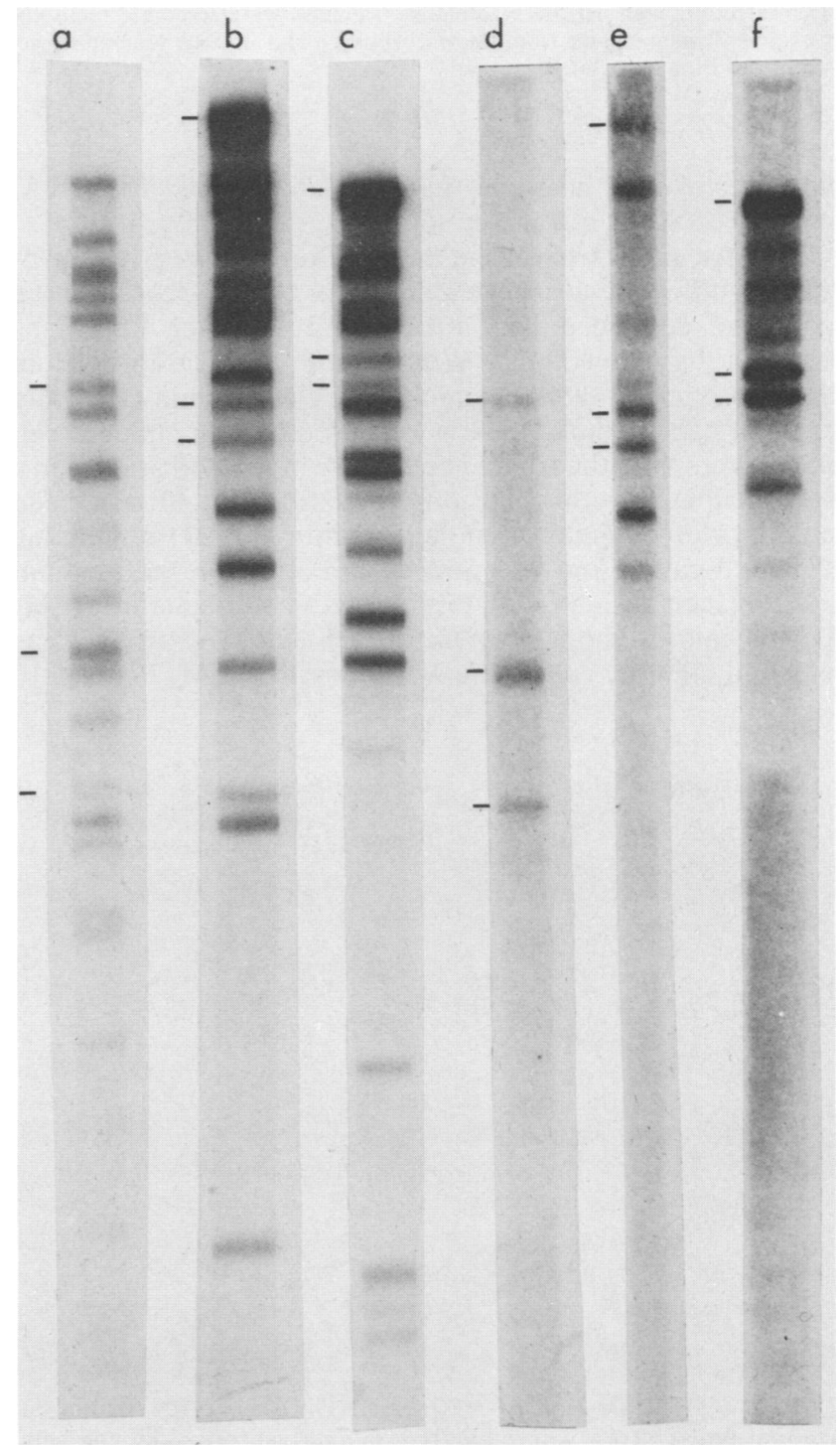

FIG. 3. Hybridization of ${ }^{32} \mathrm{P}$-labeled RNA isolated from cells infected with HCMV with nitrocellulose filters carrying HCMV DNA. Cells were labeled with $\left[{ }^{32} \mathrm{P}\right]$ orthophosphate $60 \mathrm{~h}$ after infection, and RNA was isolated as described in the text. Nitrocellulose strips containing EcoRI fragments (lanes a and d), XbaI fragments (lanes $b$ and $e$ ), and HindIII fragments (lanes $c$ and $f$ ) were hybridized with nick-translated HCMV DNA (lanes a to c) or ${ }^{32} \mathrm{P}$ labeled RNA (lanes d to f). The fragments indicated are EcoRI-G, $M$, and $L_{T}$ (lanes a and d), $X b a-B$ and $L_{T}$ (lanes $b$ and e), and HindIII-C and $\mathrm{L}_{\mathrm{T}}$ (lanes $\mathrm{c}$ and $\mathrm{f}$ ). The major fragments correspond to the map location in the L-unique region indicated in Fig. 1, and the $\mathrm{L}_{\mathrm{T}}$ fragments and EcoRI-M correspond to the terminal and junction regions of cytomegalovirus DNA. 
TABLE 1. Hybridization of RNA versus plasmid DNA immobilized on filters ${ }^{a}$

\begin{tabular}{lcr}
\hline Plasmid & RI fragment & cpm \\
\hline pHD7 & G & 3,825 \\
pHD9 & I & 504 \\
pHD14 & N & 1,400 \\
pHD15 & O & 302 \\
pHD20 & T & 748 \\
pHD22 & V & 242 \\
pHD13 & M & 2,291 \\
\hline
\end{tabular}

${ }^{a} 2 \mu \mathrm{g}$ of plasmid DNA was immobilized on nitrocellulose filters, and these were hybridized with $3.4 \times 10^{7} \mathrm{cpm}$ of RNA isolated from WI-38 cells $60 \mathrm{~h}$ after infection with HCMV. Duplicate samples were averaged, and the background radioactivity from filters carrying pBR322 DNA $(168 \mathrm{cpm})$ was subtracted from each sample.

nitrocellulose in the same manner as described for DNA, with $10 \times$ SSC as a transfer solution.

Transfer of DNA to cells in tissue culture. Cells grown in 5$\mathrm{cm}$ plastic wells were treated with CMV DNA by the technique described by Graham and Van der Eb (5) as modified by Stowe and Wilkie (20). The DNA-calcium phosphate precipitates containing $5 \mu \mathrm{g}$ of plasmid DNA and $10 \mu \mathrm{g}$ of calf thymus DNA were added to subconfluent cell monolayers, and the treated cells were incubated at $36^{\circ} \mathrm{C}$ in a $\mathrm{CO}_{2}$ incubator with occasional agitation for $40 \mathrm{~min}$. Ten milliliters of minimal essential medium (MEM) containing $10 \%$ fetal calf serum was added, and after $4 \mathrm{~h}$ the medium was replaced with $2 \mathrm{ml}$ of $15 \%$ dimethyl sulfoxide in MEM. After $4 \mathrm{~min}$ at room temperature, dimethyl sulfoxide was removed, and the cells were washed with MEM. Finally, 10

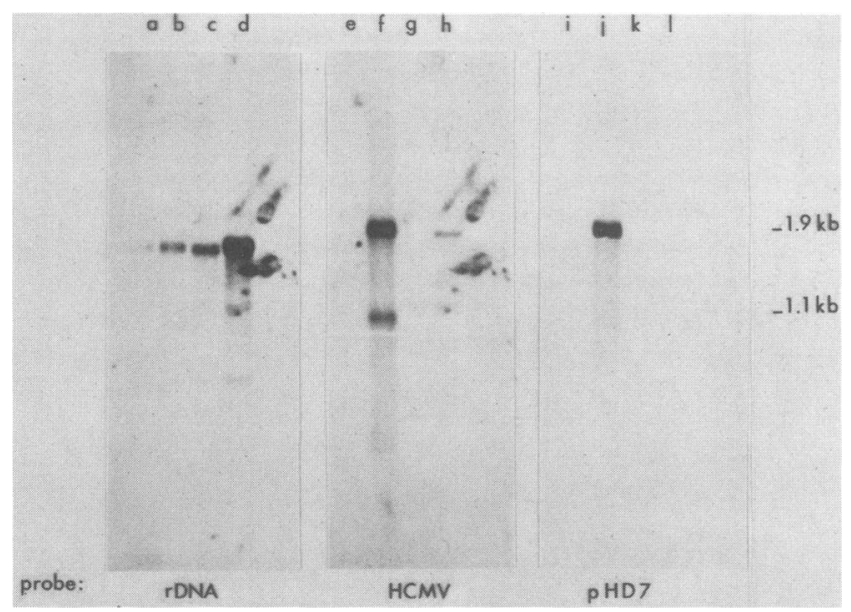

FIG. 4. Hybridization of ${ }^{32}$ P-labeled DNA with RNA immobilized on filters. RNA was separated on agarose-formaldehyde gels, blotted onto nitrocellulose filters, and hybridized with nick-translated DNA. RNA was isolated from uninfected cells (lanes a, e, and i), cells infected with HCMV $60 \mathrm{~h}$ previously (lanes $b, f$, and $j$ ), cells infected with HCMV and treated with phosphonoacetic acid (100 $\mu \mathrm{g} / \mathrm{ml}$ ) for $10 \mathrm{~h}$ (lanes $\mathrm{c}, \mathrm{g}$, and $\mathrm{k}$ ), and cells infected with HCMV and treated with cycloheximide $(50 \mu \mathrm{g} / \mathrm{ml})$ for $4 \mathrm{~h}$ (lanes $\mathrm{d}, \mathrm{h}$, and l). Nick-translated DNA probes are: rDNA, plasmid pSF2124 carrying DNA from the sea urchin Arbacia punctulata specific for 18S RNA (M. Davis, unpublished results); HCMV, total virus DNA; pHD7, plasmid pBR322 carrying EcoRI-G of HCMV. The molecular weights indicated were estimated from the size of 18S RNA (1.869 $\mathrm{kb})$ and other gels in which pBR322 DNA fragments were applied to the gels. ml of MEM containing $10 \%$ fetal calf serum was added, and the cells were incubated for $24 \mathrm{~h}$ and then harvested.

Detection of HCMV-specific antigens. Proteins from the treated cells were analyzed by SDS-polyacrylamide gel electrophoresis by the method of Laemmli (10), as previously described (11). Proteins were electroblotted onto nitrocellulose sheets, as described by Towbin et al. (21). The identification of HCMV-specific antigens was accomplished by exposing the nitrocellulose sheets to monoclonal antibody (the details of the production of monoclonal antibodies to HCMV Towne virion proteins will be published elsewhere) and then staining them with horseradish peroxidaseconjugated immunoglobulin $\mathrm{G}$ (IgG), 4-chloronapthol, and $\mathrm{H}_{2} \mathrm{O}_{2}$, as described by Hawkes et al. (7). A blue color reaction indicated the presence of antigen.

Immunoprecipitation of CMV proteins. Mock- or HCMVinfected cells were labeled for $20 \mathrm{~h}$ at $72 \mathrm{~h}$ postinfection with $\left[{ }^{35} \mathrm{~S}\right]$ methionine, $\left[{ }^{3} \mathrm{H}\right]$ glucosamine, or $\left[{ }^{32} \mathrm{P}\right]$ orthophosphate as described by Mar et al. (11). Cells were harvested by scraping, washed three times with Tris-buffered saline, and solubilized with RIPA buffer $(0.05 \mathrm{M}$ Tris hydrochloride, $0.15 \mathrm{M} \mathrm{NaCl}, 0.1 \%$ SDS, $1 \%$ sodium deoxycholate, $1 \%$ Triton X-100, $0.1 \mathrm{mM}$ phenylmethyl sulfonyl fluoride) for 30 min on ice. The lysate was sonified and centrifuged in a microcentrifuge for $15 \mathrm{~min}$. One-half milliliter of supernatant was mixed with $10 \mu \mathrm{l}$ of ascites fluid from hybridoma clone $185 \mathrm{E}, 132-5, \mathrm{H}-644$, or $\mathrm{H} 176$ and with $100 \mu \mathrm{l}$ of anti-mouse IgG (whole molecule)-agarose (Sigma Chemical Co.) and gently agitated at $4^{\circ} \mathrm{C}$ overnight. The agarose beads were collected by centrifugation, washed five times with $1 \mathrm{ml}$ of RIPA buffer, and suspended in $50 \mu$ l of sample buffer $(0.37 \mathrm{M}$ Tris hydrochloride [pH 6.8], $15 \%$ glycerol, 5\% $\beta$-mercaptoethanol, $1.5 \%$ SDS) for polyacrylamide gel electrophoresis. After heating at $90^{\circ} \mathrm{C}$ for $5 \mathrm{~min}$, the sample was cooled, the beads were pelleted, and the supernatant proteins were loaded onto a $9 \%$ polyacrylamide gel. Detection of $\left[{ }^{3} \mathrm{H}\right]$ glucosamine and ${ }^{35} \mathrm{~S}$-labeled proteins was done by fluorography (1), and detection of ${ }^{32} \mathrm{P}$-labeled proteins was done by direct exposure of gels to X-ray film, enhanced by a Cronex Lightning-Plus intensifying screen.

\section{RESULTS}

Physical map of HCMV Towne strain. Each recombinant plasmid was nick translated and hybridized to blotted restriction fragments of total viral DNA. The results of these experiments were compared with data obtained by crossblot hybridization. In addition, restriction enzyme sites were mapped on the recombinant plasmids. Physical maps of strains Davis (3), AD169 (18), and Towne (LaFemina and Hayward, personal communication) are similar to the ones shown in Fig. 1, but the regions at each end and near the L-S junction vary. These points of variability between the maps of high- and low-passage Towne strain are indicated by asterisks.

Mapping regions of transcription on the genome of HCMV. Hybridization of ${ }^{32} \mathrm{P}$-labeled RNA isolated from cells at any time between 14 and $96 \mathrm{~h}$ after infection with filters containing restriction enzyme fragments of HCMV DNA yields a complex pattern (Fig. 3), indicating that many regions are being transcribed (22). We focused on the sites of abundant transcription at the late stage of infection as shown by the intensity of the hybridization of labeled RNA with blotted DNA fragments (Fig. 3 and Table 1) and by the reverse method, hybridization of nick-translated DNA fragments with RNA immobilized on nitrocellulose filters (Fig. 4). In Fig. 4, the hybridized filters were developed after short 


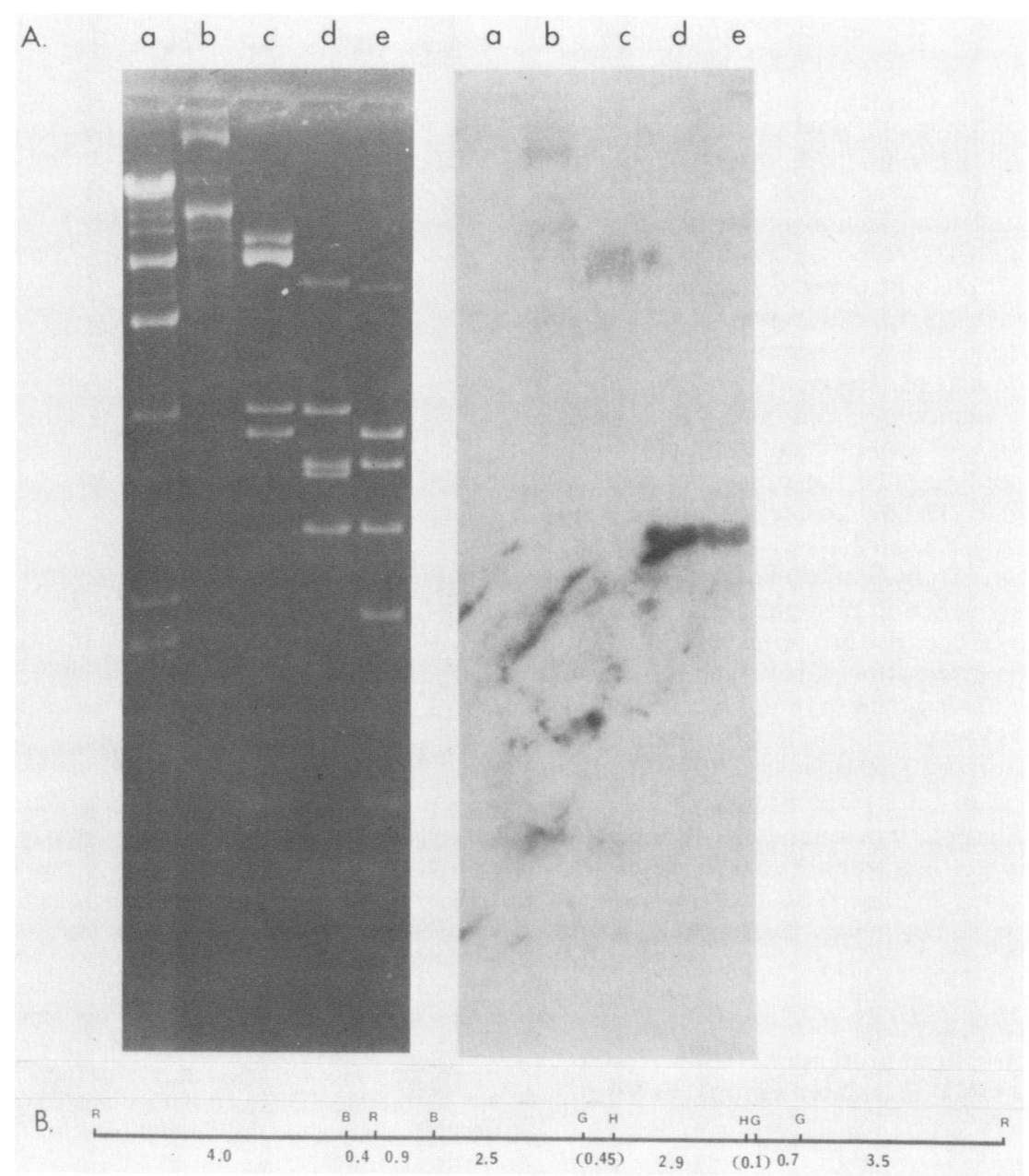

FIG. 5. Physical map of plasmid pHD7. An agarose gel (left) carrying restriction enzyme fragments of plasmid pHD7 was blotted onto nitrocellulose paper which was hybridized with ${ }^{32} \mathrm{P}$-labeled RNA isolated from cells $60 \mathrm{~h}$ after infection with HCMV (right). Lanes: a, $\lambda$ DNA digested with HindIII; b, undigested plasmid pHD7; c, pHD7 digested with EcoRI and BamHI; d, pHD7 digested with EcoRI and Bg/II; and e, pHD7 digested with EcoRI, BamHI, and BgllI. (B) A map of plasmid pHD7 indicating the orientation of pBR322 (4.4 kb) and sites for EcoRI (R), BamHI (B), BglII (G), and Hinfl (H). The orientation shown is the orientation of fragment EcoRI-G on the map shown in Fig. 1, and the transcription of $1.9 \mathrm{~kb}$ RNA is from left to right. The Hinfl sites have been mapped by DNA sequencing experiments (data not shown). Only the terminal Hinfl sites are indicated on the 2.9-kb BglII fragment.

exposure, to show only the most intense labeling. Two distinct regions of transcription located by these experiments are indicated below the EcoRI restriction map (Fig. 1 ), one of these near the L-S junction and the other at the middle of the L-unique region. Much of the complex pattern of hybridization of RNA with EcoRI digestion fragments can be attributed to the multiple L-S junction and L-repeat fragments which are distributed throughout the size range (LaFemina and Hayward, personal communication) and which hybridize to an abundant 1.1-kb RNA (Fig. 4 and Table 1). This transcription region is represented at least twice in every virus molecule, at the L-S junction and at the $L$ terminus. At longer exposure, probably all restriction fragments of HCMV hybridizes with ${ }^{32} \mathrm{P}$-labeled RNA isolated from cells late in infection.

A comparison of the abundance of these two major transcripts with others was performed by hybridizing ${ }^{32} \mathrm{P}$ labeled RNA in solution with filters containing recombinant plasmid DNA (Table 1).

The results are comparable with those previously deter- mined for total viral DNA blots, although neither experiment is corrected to molarity by estimating the sizes of the RNA. Fragment G carried by plasmid pHD7 was labeled 15-fold more intensely than fragments $\mathrm{V}$ or $\mathrm{O}$, and fragment $\mathrm{M}$, which carries part of the L-repeat DNA, was ninefold more radioactive than fragment V. As demonstrated in Fig. 4, the RNA hybridizing to fragment $G$ is a late transcript of $1.9 \mathrm{~kb}$. This RNA was not present in cells treated with cycloheximide or phosphonoacetic acid after virus infection.

Isolation of one region of transcription. The most intensely labeled fragment, EcoRI-G carried by plasmid pHD7, was fragmented by enzyme $B$ glII into four portions, one of which hybridized to RNA isolated from infected cells (Fig. 5). This 2.9-kb $B g$ lII fragment is the only transcribed region we have detected in the original 11.7-kb EcoRI fragment. This observation was confirmed by electron microscope observation of R-loops, which show a single uninterrupted region of hybridization (L. Loh and E.-S. Huang, unpublished data). The 2.9-kb BgllI fragment was subcloned into the BamHI site of bacteriophage $\mathrm{M} 13 \mathrm{mp} 7$, and the fragment which was re- 
leased after $E c o$ RI digestion of the replicative-form DNA of the recombinant M13-713 was recombined into the EcoRI site of plasmid pSV-OH (Fig. 2).

Plasmids resulting from the recombination between M13713 and plasmid pSV-OH were divided into two groups, based on digestion patterns with enzyme HinfI. Plasmid pHD713SV1 carries the inserted region in the orientation opposite to that in plasmid pHD713SV2 (Fig. 2).

Expression of the $67 \mathrm{~K}$ protein in tissue culture cells. Cultures of HEL cells and COS-1 cells were treated with plasmid DNA as described above, and protein was extracted and applied to acrylamide gels as described. Electroblotted protein was reacted with monoclonal antibody prepared in this laboratory specific for a 67,000 -molecular-weight $(67 \mathrm{~K})$ protein of HCMV. A photograph of the stained nitrocellulose paper is shown in Fig. 6 . The $67 \mathrm{~K}$ protein was produced in COS- 1 cells carrying pHD713SV2 DNA but not in cells carrying pHD713SV1 DNA. The orientation of the transcription of the $67 \mathrm{~K}$ protein sequence in plasmid pHD713SV2 is downstream from the major early promoter of SV40. In plasmid pHD713SV1, this orientation is reversed.

Characterization of the $67 \mathrm{~K}$ protein in infected cells. WI-38 cells infected with HCMV were labeled with $\left[{ }^{3} \mathrm{H}\right]$ glucosamine, $\left[{ }^{35} \mathrm{~S}\right]$ methionine, or $\left[{ }^{32} \mathrm{P}\right]$ orthophosphate $72 \mathrm{~h}$ after infection. After extraction of total protein, the $67 \mathrm{~K}$ protein was immunoprecipitated with monoclonal antibody, and the protein was analyzed by gel electrophoresis. The gel was exposed to X-ray film (Fig. 7). The $67 \mathrm{~K}$ protein was not labeled by $\left[{ }^{3} \mathrm{H}\right]$ glucosamine, but it was labeled by ${ }^{32} \mathrm{P}$ and ${ }^{35} \mathrm{~S}$.

\section{DISCUSSION}

The $67 \mathrm{~K}$ protein is a structural protein of HCMV, in fact, one of the major proteins found in isolated virions (Fig. 6 and

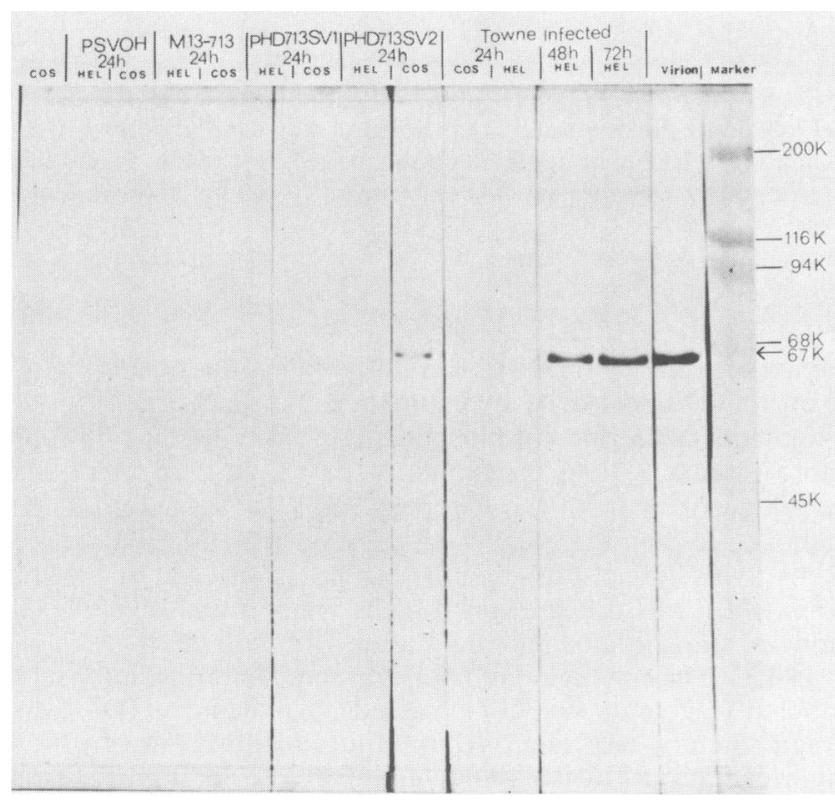

FIG. 6. Immunoperoxidase stain of blotted proteins isolated from cells carrying HCMV DNA. Cultures of HEL cells and COS-1 cells were treated with the plasmid DNA indicated or infected with HCMV. Protein was extracted from the cultures and from isolated virions, isolated as previously described (8), applied to acrylamide gels, and separated by electrophoresis. Electroblotted protein was reacted with monoclonal antibody and stained with horseradish

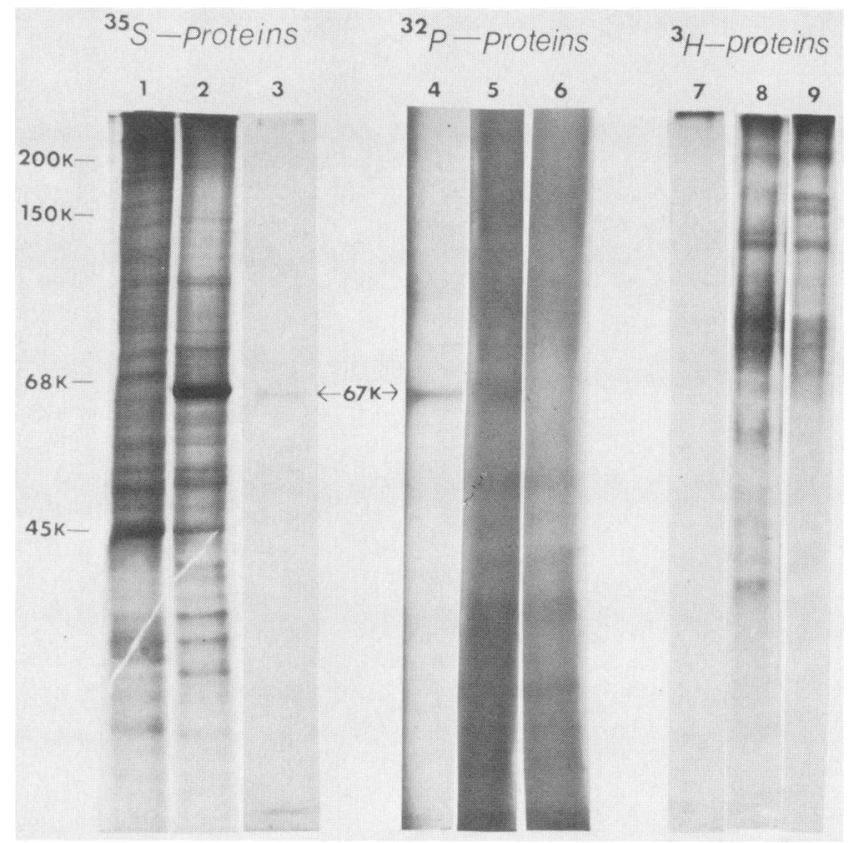

FIG. 7. Immunoprecipitation of polypeptides of HCMV-infected cells labeled with $\left[{ }^{35} \mathrm{~S}\right]$ methionine, $\left[{ }^{3} \mathrm{H}\right]$ glucosamine, or $\left[{ }^{32} \mathrm{P}\right]$ orthophosphate by a monoclonal antibody. The immunoprecipitates were subjected to SDS-polyacrglamide gel electrophoresis as described in the text. Lanes 1,6 , and 9 contain host cell proteins labeled with $\left[{ }^{35} \mathrm{~S}\right]$ methionine, $\left[{ }^{32} \mathrm{P}\right]$ orthophosphate, and $\left[{ }^{3} \mathrm{H}\right]$ glucosamine, respectively. Lanes 2,5 , and 8 contain infected cell proteins labeled with $\left[{ }^{35} \mathrm{~S}\right]$-methionine, $\left[{ }^{32} \mathrm{P}\right]$ orthophosphate, and $\left[{ }^{3} \mathrm{H}\right]$ glucosamine, respectively. Lanes 3,4 , and 7 contain labeled polypeptides precipitated from HCMV-infected cell extracts by monoclonal antibody. No detectable $\left[{ }^{3} \mathrm{H}\right]$ glucosamine-labeled protein was precipitated (lane 7), although a $67 \mathrm{~K}$ protein was precipitated from ${ }^{35} \mathrm{~S}$ - and ${ }^{32} \mathrm{P}$ labeled cultures.

7). The monoclonal antibody which reacts with the $67 \mathrm{~K}$ protein does not neutralize virus infectivity, indicating that the protein may be internal. It probably corresponds to the $66 \mathrm{~K}$ phosphorylated protein described by Gibson (4), a tegument protein which interfaces the capsid and the membrane of the virus. A $64 \mathrm{~K}$ glycoprotein recently described by Clark et al. (2) is unrelated to the $67 \mathrm{~K}$ phosphoprotein (Fig. 7). The monoclonal antibody preparation which precipitates the $67 \mathrm{~K}$ protein fails to precipitate a labeled protein from infected cell proteins labeled with $\left[{ }^{3} \mathrm{H}\right]$ glucosamine. The gene for the $64 \mathrm{~K}$ glycoprotein of Clark et al. is carried by fragment EcoRI-A (H. Pande, S. Baak, J. A. Zaia, B. R. Clark, J. E. Shively, and A. D. Riggs, Eighth International Herpesvirus Workshop, Oxford, abstr. no. 272, 1983).

The RNA transcripts that we describe have also been identified by Wathen and Stinski (22). We do not detect the larger RNAs that they describe, but the smaller species at 1.9 and $1.2 \mathrm{~kb}$ correspond to the map locations that we report for 1.9- and 1.1-kb RNA.

The intense transcription of L-repeat regions was also found in cells infected with strain Ad169 of CMV (13). The 1.9-kb transcript we describe probably corresponds to RNA

peroxidase-conjugated IgG, 4-chloronaphthol, and $\mathrm{H}_{2} \mathrm{O}_{2}$. Only COS- 1 cells carrying DNA of plasmid pHD713SV2 had detectable amounts of a $67 \mathrm{~K}$ protein. 
hybridizing to EcoRI-I of Ad169, although it is not characterized as the most abundant transcript from analysis of cytoplasmic, polyadenylated RNA. McDonough and Spector (13) describe strain differences in the pattern of transcription in CMV-infected cells. Spector et al. (18) also have mapped a 3-kb $B g$ III fragment (BglII-X) in EcoRI-I, flanked by a 0.78$\mathrm{kb}$ fragment ( $B g$ lII-f). The orientation of these fragments has been determined by DNA sequencing and cross-hybridization of internal fragments in this laboratory (Fig. 5). The $\mathrm{L}$ segment of HCMV in maps of Ad169 is inverted relative to the orientation illustrated in Fig. 1. It appears that the region near 0.4 map units is the same between these strains; indeed, it is likely that most of the genomes of cytomegalovirus strains are genetically colinear (23). Variations are clustered at the repeat termini, and these are probably responsible for nonhomologous sequences between strains (15).

We have not determined whether the 2.9-kb BglII fragment carries a functional promoter, since cells expressed the $67 \mathrm{~K}$ protein only when transfected with recombinant plasmid DNA of pHD713SV2 which carries HCMV DNA downstream from an early promoter of SV40, and only COS-1 cells expressed the protein at a detectable level. Expression of the $67 \mathrm{~K}$ protein was not detected in human embryonic lung cells transfected with either pHD713SV1 or pHD713SV2 DNAs. If a viral promoter is located on the $B g / I I$ fragment, it does not promote the expression of the $67 \mathrm{~K}$ protein when dissected from the total HCMV viral DNA. Evidently, an early or immediate early viral function is required for expression of the $67 \mathrm{~K}$ protein. We can investigate this requirement by measuring protein expression in cells after transfer of pHD713SV1 DNA in combination with other recombinant plasmids or after microinjection of HCMV macromolecules.

We identified a putative promoter on the $B g$ lII fragment by DNA sequence analysis of the DNA insertion of M13-713 bacteriophage. The $5^{\prime}$ end of the RNA is located $300 \mathrm{bp}$ from one $B$ glII site, and no intervening sequences were detected. The DNA sequence $5^{\prime}$ to the site of RNA initiation is abruptly different from the surrounding sequence. Five hundred base pairs from the initiation site, the $\mathrm{G}+\mathrm{C}$ content of the DNA is $66 \%$. In contrast, the 230 bp before the initiation site contain $29 \% \mathrm{G}+\mathrm{C}$. The entire coding region including $700 \mathrm{bp}$ downstream is $50 \% \mathrm{G}+\mathrm{C}$, and the most distant sequence that has been determined, 700 to $900 \mathrm{bp}$ after the polyadenylation signal, is $66 \% \mathrm{G}+\mathrm{C}$. A definite gene structure is evident from this analysis (M. G. Davis and E.-S. Huang, manuscript in preparation).

The entire sequence consists of surrounding viral DNA of high $\mathrm{G}+\mathrm{C}$ content, abruptly interrupted by an extended A $+\mathrm{T}$-rich region, followed by an information sequence that contains maximum nucleotide variability. We plan similar analyses of other coding regions of human cytomegalovirus to determine the function of these regions, their distribution, and their controlling elements. Analysis of similar coding regions of other herpesviruses, identified by cross-hybridization of the CMV coding region and restriction fragments of herpesvirus DNA, may indicate similar functions in other members of the virus group.

\section{LITERATURE CITED}

1. Bonner, W. M., and R. A. Laskey. 1974. A film detection method for tritium-labelled proteins and nucleic acids in polyacrylamide gels. Eur. J. Biochem. 46:83-88.

2. Clark, B. R., J. A. Zaia, L. Balce-Directo, and Y.-P. Ting. 1984.
Isolation and partial chemical characterization of a 64,000 dalton glycoprotein of human cytomegalovirus. J. Virol. 49:279-282.

3. Demarchi, J. M. 1981. Human cytomegalovirus DNA: restriction enzyme cleavage maps and map locations for immediateearly, early, and late RNAs. Virology 114:23-38.

4. Gibson, W. 1981. Structural and nonstructural proteins of strain Colburn cytomegalovirus. Virology 111:516-537.

5. Graham, F. L., and A. J. Van der Eb. 1973. A new technique for the assay of activity of human adenovirus 5 DNA. Virology 52:456-467.

6. Grunstein, M., and D. Hogness. 1975. Colony hybridization: a method for the isolation of cloned DNAs that contain a specific gene. Proc. Natl. Acad. Sci. U.S.A. 72:3961-3965.

7. Hawkes, R., E. Niday, and A. Matus. 1982. Monoclonal antibodies identify novel neural antigens. Proc. Natl. Acad. Sci. U.S.A. 79:2410-2414.

8. Huang, E.-S., S.-T. Chen, and J. S. Pagano. 1973. Human cytomegalovirus. I. Purification and characterization of viral DNA. J. Virol. 12:1473-1481.

9. Huang, E.-S., S.-M. Huong, G. E. Tegtmeier, and C. Alford. 1980. Cytomegalovirus: genetic variation of viral genomes. Ann. N.Y. Acad. Sci. 354:332-346.

10. Laemmli, U. K. 1970. Cleavage of structural proteins during the assembly of the head of bacteriophage T4. Nature (London) 227:680-685.

11. Mar, E.-C., P. C. Patel, and E.-S. Huang. 1982. Effect of 9-(2hydroxyethoxymethyl) guanine on viral-specific polypeptide synthesis in human cytomegalovirus-infected cells. Am. J. Med. 73:82-85.

12. Maxam, A. M., and W. Gilbert. 1980. Sequencing end-labeled DNA with base-specific chemical cleavages. Methods Enzymol. 65:49-560.

13. McDonough, S. H., and D. H. Spector. 1983. Transcription in human fibroblasts permissively infected by human cytomegalovirus strain AD169. Virology 125:31-46.

14. Nelson, J. A., B. Fleckenstein, D. A. Galloway, and J. K. McDougall. 1982. Transformation of NIH 3T3 cells with cloned fragments of human cytomegalovirus strain AD169. J. Virol. 43:83-91.

15. Pritchett, R. F. 1980. DNA nucleotide sequence heterogeneity between the Towne and AD169 strains of cytomegalovirus. J. Virol. 36:152-161.

16. Seeburg, P. H., J. Shine, J. Martial, A. Ulirich, J. D. Baxter, and H. M. Goodman. 1977. Nucleotide sequence of part of the gene for human chorionic somatomammotropin: purification of DNA complementary to predominant mRNA species. Cell 12:157165.

17. Southern, E. M. 1975 . Detection of specific sequences among DNA fragments separated by gel electrophoresis. J. Mol. Biol. 98:503-517.

18. Spector, D. H., L. Hock, and J. C. Tamashiro. 1982. Cleavage maps for human cytomegalovirus DNA strain AD169 for restriction endonucleases EcoRI, BglII, and HindIII. J. Virol. 42:558582 .

19. St. Jeor, S. C., and R. Hutt. 1977. Cell DNA replication as a function in the synthesis of human cytomegalovirus. J. Gen. Virol. 37:65-73.

20. Stow, N. D., and N. M. Wilkie. 1976. An improved technique for obtaining enhanced infectivity with herpes simplex virus type 1 DNA. J. Gen. Virol. 33:447-458.

21. Towbin, H., T. Staehelin, and J. Gordon. 1979. Electrophoretic transfer of proteins from polyacrylamide gels to nitrocellulose sheets: procedure and some applications. Proc. Natl. Acad. Sci. U.S.A. 76:4350-4354.

22. Wathen, M. W., and M. F. Stinski. 1982. Temporal patterns of human cytomegalovirus transcription: mapping the viral RNAs synthesized at immediate early, early, and late times after infection. J. Virol. 41:462-477.

23. Westrate, M. W., J. L. M. C. Geelen, P. M. E. Wertheim, and J. Van der Noordaa. 1983. Comparison of the physical maps of the DNAs of two cytomegalovirus strains. J. Gen. Virol. 64:47-55. 